\title{
A tiny new species of Platypelis from the Marojejy National Park in northeastern Madagascar (Amphibia: Microhylidae)
}

Glaw F., Köhler J. \& Vences M. 2012. A tiny new species of Platypelis from the Marojejy National Park in northeastern Madagascar (Amphibia: Microhylidae). European Journal of Taxonomy 9: 1-9. http://dx.doi. org/10.5852/ejt.2012.9

\author{
Frank GLAW ${ }^{1}$, Jörn KÖHLER ${ }^{2}$ \& Miguel VENCES 3 ,4 \\ 'Zoologische Staatssammlung München, Münchhausenstr. 21, 81247 München, Germany. \\ ${ }^{2}$ Hessisches Landesmuseum Darmstadt, Friedensplatz 1, 64283 Darmstadt, Germany. \\ ${ }^{3}$ Division of Evolutionary Biology, Zoological Institute, Technical University of Braunschweig, \\ Mendelssohnstr.4, 38106 Braunschweig, Germany. \\ [Email: m.vences@tu-bs.de
}

\begin{abstract}
We describe a tiny new frog species of the genus Platypelis (Anura: Microhylidae: Cophylinae) from Marojejy National Park, northeastern Madagascar. Platypelis ravus sp. nov. differs from all other known Platypelis and Cophyla species by its small size (17-19 mm snout-vent length) and a combination of other morphological and bioacoustic characters. The new species seems to be most closely related to P. milloti with which it shares the principal colour pattern, but exhibits a yellow rather than red posterior venter. Uncorrected pairwise sequence divergence in a 16S rRNA gene fragment to all other known species of the genus (except $P$. cowanii for which no genetic data is available) is greater than $6 \%$. We suggest the inclusion of the new species in the IUCN threat category "Data Deficient".
\end{abstract}

Key words. Microhylidae, Cophylinae, Platypelis ravus sp. nov., Madagascar, Marojejy National Park.

\section{Introduction}

Narrow-mouthed frogs, family Microhylidae Günther, 1858, are a species-rich clade of almost cosmopolitan distribution and only partly clarified phylogenetic relationships (Van Bocxlaer et al. 2006; Van der Meijden et al. 2007; Kurabayashi et al. 2011). Madagascar's microhylids are classified in three endemic subfamilies, Cophylinae Cope, 1889, Dyscophinae Boulenger, 1882 and Scaphiophryninae Laurent, 1946 (Blommers-Schlösser \& Blanc 1991) of which the Cophylinae is by far the most speciesrich group and sister to the Scaphiophryninae (Van der Meijden et al. 2007). Cophylines are characterized by the presence of endotrophic (non-feeding) tadpoles that develop either in water-filled tree holes or similar cavities, in foam nests, or in subterraneous jelly nests (Blommers-Schlösser 1975; Glaw \& Vences 2007). With few exceptions, the advertisement calls of cophyline species are highly stereotyped, consisting of regularly repeated single notes which typically are melodious whistles or clicks (Vences et al. 2006).

According to Glaw \& Vences (2007) and subsequent species descriptions (summarized in AmphibiaWeb 2012), cophylines currently comprise seven genera with altogether 58 species: Anodonthyla Müller, 
1892 (11 species), Cophyla Boettger, 1880 (3 species), Madecassophryne Guibé, 1974 (1 species), Platypelis Boulenger, 1882 (10 species), Plethodontohyla Boulenger, 1882 (10 species), Rhombophryne Boettger, 1880 (10 species), and Stumpffia Boettger, 1881 (13 species). These frogs have radiated into a variety of niches and contain arboreal, terrestrial and fossorial frogs (Andreone et al. 2005; Wollenberg et al. 2008). The subfamily contains species as large as $100 \mathrm{~mm}$ and miniaturized species as small as $10 \mathrm{~mm}$ snout-vent length (Glaw \& Vences 2007). Field surveys and molecular assessments of diversity (e.g. Vieites et al. 2009) have provided evidence that the species inventory of the cophylines is far from being completed, and a large number of undescribed candidate species is known from most of the cophyline genera.

Arboreal cophylines include the genera Anodonthyla, Cophyla, Platypelis and a few species of the genus Plethodontohyla. Anodonthyla is relatively well characterized by the presence of a distinct prepollex in males and the absence of vomerine teeth. The distinction of Cophyla and Platypelis is less clear and mainly based on osteological characters (Blommers-Schlösser \& Blanc 1991). Cophyla is the sister group of Platypelis based on molecular data (Wollenberg et al. 2008).

During fieldwork in 2005, we collected specimens of a Platypelis from the Marojejy National Park in northeastern Madagascar that distinctly differ from all cophylines known so far. We describe this new species in the following.

\section{Material and Methods}

Specimens were collected at night by opportunistic searching and localizing calling males, using torches and head lamps. They were euthanized in a chlorobutanol solution, fixed in 95\% ethanol and preserved in $70 \%$ ethanol. Locality information was recorded with GPS receivers. Type specimens of the new species are deposited in the Zoologische Staatssammlung München (ZSM) and the Université d'Antananarivo, Département de Biologie Animale, Madagascar (UADBA). FGZC refers to F. Glaw field numbers. Terminology for biogeographic regions of Madagascar follows Glaw \& Vences (2007).

Morphological measurements (in millimetres) were all taken by M. Vences with a digital caliper (precision $0.01 \mathrm{~mm}$ ) to the nearest $0.1 \mathrm{~mm}$. Used abbreviations are: SVL (snout-vent length), HW (greatest head width), HL (head length), ED (horizontal eye diameter), END (eye-nostril distance), NSD (nostril-snout tip distance), NND (nostril-nostril distance), TD (horizontal tympanum diameter), TL (tibia length), HAL (hand length), HIL (hindlimb length), FL (foot length), FOTL (foot length including tarsus), FORL (forelimb length), and RHL (relative hindlimb length). Terminology and description scheme follow Vences et al. (2010).

Calls were recorded in the field using a Sony WM-D6C tape recorder and external microphones (Sennheiser Me-80, Vivanco EM 238). Recordings were sampled at $22.05 \mathrm{kHz}$ and 16-bit resolution and computer-analysed using the software Adobe Audition. Frequency information was obtained through Fast Fourier Transformation (FFT; width 1024 points). The spectrogram was obtained at Hanning window function with 256 bands resolution. Temporal measurements are given as range, with mean \pm standard deviation in parentheses. Terminology in call description follows Vences et al. (2010).

Molecular genetic analyses were conducted by Wollenberg et al. (2008) and Vieites et al. (2009). See those studies for exact methodology applied. 


\title{
Results
}

\author{
Class Amphibia Gray, 1825 \\ Order Anura Fischer von Waldheim, 1813 \\ Family Microhylidae Günther, 1858 \\ Subfamily Cophylinae Cope, 1889 \\ Genus Platypelis Boulenger, 1882
}

Platypelis ravus sp. nov.

\section{Remark}

This species has been referred to as Platypelis sp. (Marojejy) by Vences et al. (2006), as Platypelis sp. aff. mavomavo 2 by Glaw \& Vences (2007), as Platypelis sp. 2 by Wollenberg et al. (2008) and as Platypelis sp. 4 by Vieites et al. (2009).

\section{Etymology}

The specific epithet is an adjective derived from Latin ravus = grayish-yellow, referring to the diagnostic ventral colour of the species.

\section{Holotype}

ZSM 349/2005 (field number FGZC 2813), adult $\hat{\partial}$, collected at Marojejy National Park, 'Camp Simpona', $14^{\circ} 26.199^{\prime} \mathrm{S} 49^{\circ} 44.601^{\prime} \mathrm{E}, 1326 \mathrm{~m}$ above sea level, Antsiranana Province, northeastern Madagascar, on 15 Feb. 2005 by F. Glaw, M. Vences, and R.D. Randrianiaina.

\section{Paratypes}

ZSM 350/2005 (field number FGZC 2823) and ZSM 351/2005 (FGZC 2824), two adult $\hat{\jmath}-\widehat{\partial}$, with same data as holotype, except that ZSM 351/2005 was collected on 16 Feb. 2005. Three additional paratypes, all $\widehat{\sigma}-\hat{O}$ collected while calling, were deposited in the UADBA collection (still uncatalogued) and are labelled with the field numbers FGZC 2822, 2825 and 2869. Their collection data are the same as in the holotype except for FGZC 2869 (collected on 16 May 2005).

\section{Diagnosis}

The new species is assigned to the genus Platypelis based on enlarged terminal finger discs, absence of prepollex, and molecular phylogenetic relationships (Wollenberg et al. 2008). It differs from other arboreal cophyline microhylids of the genus Anodonthyla by the absence of a prepollex in males, and from Plethodontohyla with enlarged finger and toe discs [P. guentheri Glaw \& Vences, 2007, $P$. inguinalis Boulenger, 1882, P. mihanika Vences, Raxworthy, Nussbaum \& Glaw, 2003, P. notosticta (Günther, 1877)] by much smaller size (SVL 17-19 mm vs. 26-100 mm). Within the Platypelis / Cophyla clade, the species is distinguished from Cophyla berara Vences, Andreone \& Glaw, 2005, C. phyllodactyla Boettger, 1880, Platypelis alticola (Guibé, 1974), P. cowanii Boulenger, 1882, P. grandis (Boulenger, 1889), P. mavomavo Andreone, Fenolio \& Walvoord, 2003, P. milloti Guibé, 1950, P. pollicaris Boulenger, 1888, P. tsaratananaensis Guibé, 1974, and P. tuberifera (Methuen, 1920) by distinctly smaller size (SVL of adult males $17-19 \mathrm{~mm}$ vs. 23-88 mm), and from P. tetra Andreone, Fenolio \& Walvoord, 2003 by presence of a regular pattern of moderately-sized tubercles on the back (vs. four symmetrically arranged and distinctly enlarged white tubercles), a third toe of the same length than the fifth (vs. toe three longer than toe five), by presence of yellow ventral colouration (vs. absence), and by a much higher note repetition rate of the advertisement calls. It differs from Cophyla occultans (Glaw \& Vences, 1992) by smaller size (SVL 17-19 mm vs. 18-21 mm), and equal length of toe 3 and 5 (vs. toe $3<5$ ). It is distinguished from Platypelis barbouri Noble, 1940 (and most likely from its junior 
synonym Paracophyla tuberculata Millot \& Guibé, 1951, described from the well sampled type locality Andasibe) by absence of red colour on the ventral side of the hindlimbs and belly, and a largely smooth dorsal surface (vs. strongly tuberculate).

Summarizing, the new species is most similar to P. barbouri (the only other Platypelis without vomerine teeth and in addition with a rather similar advertisement call, but with reddish instead of yellow ventral surface, and more strongly expressed and irregularly arranged tubercles on dorsal surface), and to $P$. mavomavo (with yellow ventral surface but distinctly larger SVL). It differs, however, from these and all other nominal species of Platypelis and Cophyla (except $P$. cowanii for which no genetic data is available) by a high genetic divergence (see Wollenberg et al. 2008; Vieites et al. 2009 and unpublished data for P. alticola, P. tsaratananaensis, P. tetra and Cophyla occultans). Phylogenetically, it appears to be sister to P. milloti (see below) which however is larger, has a much more contrasting dorsal pattern, red colour ventrally, and a much faster note repetition rate in advertisement calls (106/min vs. 18-19/ $\min )$.

\section{Description of the holotype}

Specimen in good state of preservation, some muscle tissue removed from right thigh, snout-vent length $19.1 \mathrm{~mm}$. Body slender; head as wide as long, not wider than body; snout bluntly rounded in dorsal and lateral views; nostrils directed dorsolaterally, not protuberant, nearer to tip of snout than to eye; canthus rostralis indistinct, very slightly concave; loreal region plain; tympanum moderately distinct, $56 \%$ of eye diameter; supratympanic fold moderately distinct, straight; tongue ovoid, not bifid or notched; weakly expressed maxillary teeth present; vomerine teeth absent; choanae rounded. Forelimbs slender; subarticular tubercles single, flat, and hardly recognizable; outer metacarpal tubercle probably large and flat, but very difficult to recognize; inner metacarpal tubercle large, forming distinct protuberance at base of first finger; hand with traces of webbing only between fingers 3 and 4; fingers distinctly flattened and relatively broad along entire length; relative length of fingers $1<2<4<3$, fourth finger distinctly longer than second; finger discs distinctly enlarged, slightly triangular; nuptial pads absent. Hindlimbs slender; tibiotarsal articulation reaching tympanum when hindlimb adpressed along body; tibia length, $39 \%$ of SVL; lateral metatarsalia strongly connected; inner metatarsal tubercle small and flat, difficult to recognize; outer metatarsal tubercle absent; webbing between toes weakly developed, with traces of web between second and third toe, and some webbing between third and fouth, and fourth and fifth toe; webbing formula difficult to assess because subarticular tubercles on toes are hardly recognizable; toes flattened and relatively broad along their entire length; relative length of toes $1<2<3=5<4$; third toe of similar length as fifth. Dorsal skin smooth, without dorsolateral folds. Ventral skin slightly granular on throat, smooth on chest and moderately granular on belly.

After five years in $70 \%$ ethanol, dorsum light brown with distinct and well-delimited symmetrical dark brown markings: a heart-shaped marking starting between eyes and extending on posterior head, bordered anteriorly by a light brown band between eyes; a W-shaped marking on anterior dorsum; and a chevron-shaped marking on posterior dorsum. Shank and foot with one distinct dark crossband each, another dark crossband on anterior hand. Ventrally, the throat is dark brown and this dark colour fades at the level of the chest into a whitish colour on posterior belly. Limbs light with some dark brown pigment.

In life (Fig. 1), two series of regularly arranged and light-coloured small tubercles recognizable on the dorsum, with five and three tubercles bordering the anterior edges of the $\mathrm{W}$-shaped and chevron-shaped dark markings, respectively. In life (Fig. 1A), the colour was very similar to that in preservative but more contrasted. The interorbital band was posteriorly beige. The iris was uniformly bronze. Throat and chest were grayish. The yellow ventral colour extended onto the lateral part of the inguinal region. Also the finger and toe discs (especially of first finger) were yellowish. 


\section{Variation}

The two ZSM paratypes are very similar in external morphology and colour pattern when compared to the holotype (Table 1), but have a thin light middorsal line, and (in preservative) ventrally less dark pigment, especially in ZSM 351/2005 which is mostly light coloured ventrally. The UADBA paratypes were not available for detailed studies but were in general similar to the ZSM paratypes.
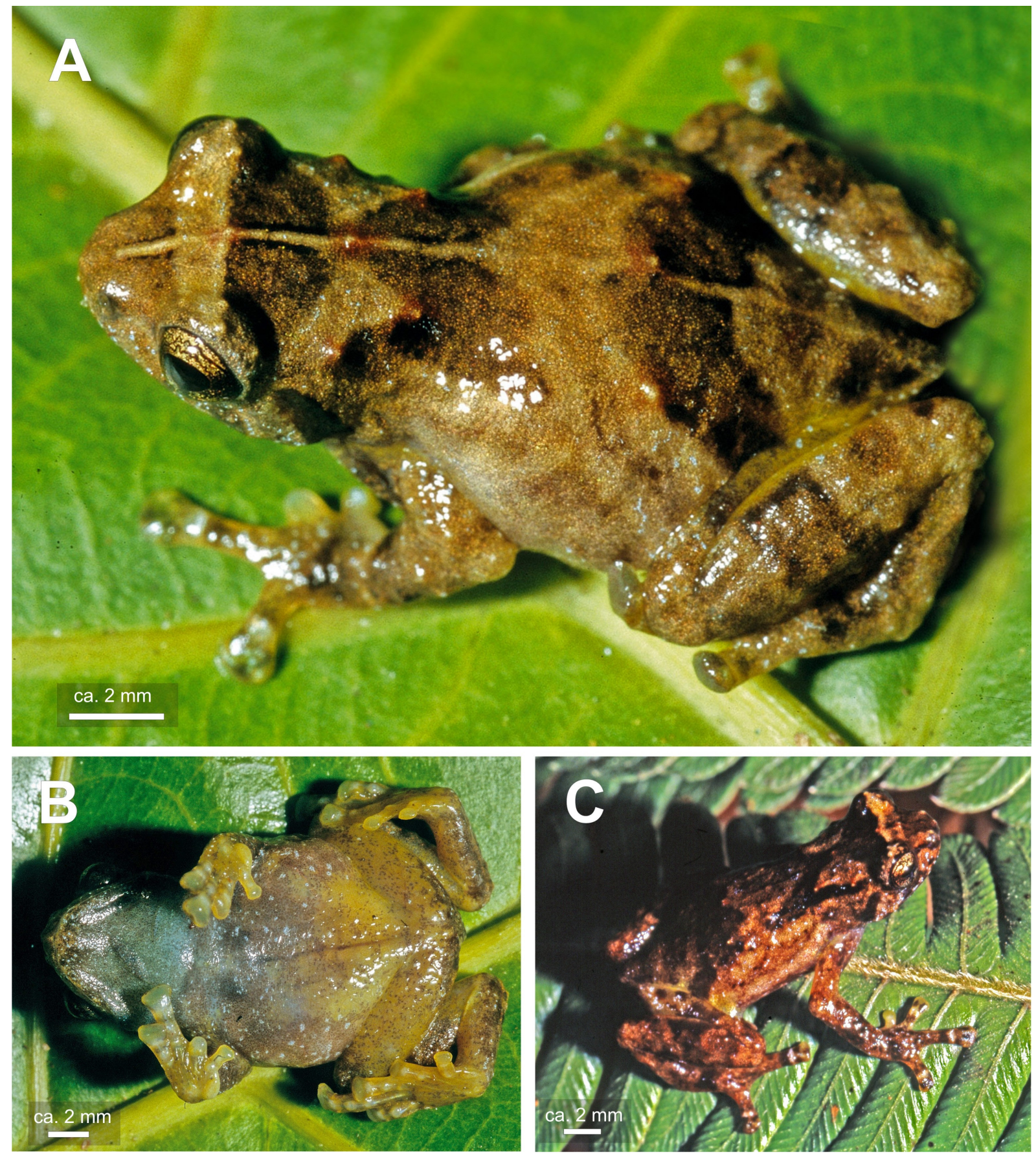

Fig. 1. Platypelis ravus sp. nov. in life. A. Dorsolateral view of $\widehat{\jmath}$ paratype (ZSM 350/2005) from Marojejy National Park. B. Ventral view of same specimen (ZSM 350/2005). C. Dorsolateral view of $\widehat{\partial}$ holotype (ZSM 349/2005). 
Table 1. Morphometric measurements (all in $\mathrm{mm}$ ) of holotype (HT) and two paratypes (PT) of Platypelis ravus. For abbreviations of measured variables, see Materials and methods; further abbreviations used: $\mathrm{M}$ (male); F (female). Tympanum diameter (TD) values in brackets indicate that the tympanum was not distinct. In all specimens, third and fifth toe were of equal length, and the tibiotarsal articulation reaches tympanum when hindlimbs are adpressed along body.

\begin{tabular}{|c|c|c|c|}
\hline & ZSM 349/2005 & ZSM 350/2005 & ZSM 351/2005 \\
\hline Field number & FGZC 2813 & FGZC 2823 & FGZC 2824 \\
\hline Status & HT & PT & PT \\
\hline Sex & M & M & M \\
\hline SVL & 19.1 & 17.9 & 17.2 \\
\hline HW & 6 & 5.8 & 5.4 \\
\hline HL & 6 & 5.6 & 5.5 \\
\hline TD & 1.4 & 1.1 & 1.2 \\
\hline ED & 2.5 & 2.4 & 2.4 \\
\hline END & 1.5 & 1.4 & 1.5 \\
\hline NSD & 1.1 & 1.4 & 1.2 \\
\hline NND & 2.2 & 2 & 2 \\
\hline HAL & 5.5 & 5.2 & 4.8 \\
\hline FORL & 11.2 & 10.9 & 10.7 \\
\hline HIL & 25.8 & 25.7 & 21.7 \\
\hline FOTL & 11.8 & 11.4 & 10.4 \\
\hline FL & 7.4 & 7.1 & 6.3 \\
\hline TL & 7.5 & 7.8 & 7.1 \\
\hline
\end{tabular}
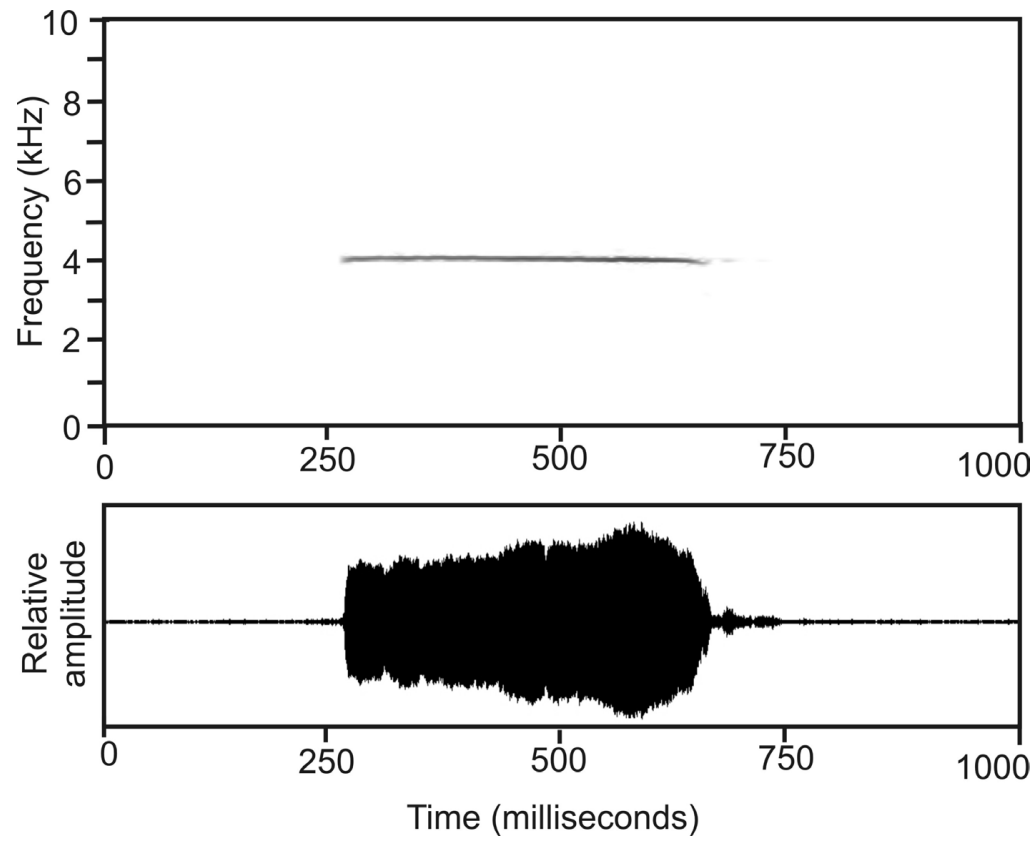

Fig. 2. Audiospectrogram and corresponding oscillogram of the advertisement call of the holotype of Platypelis ravus sp. nov. (ZSM 349/2005), recorded at Camp Simpona, Marojejy National Park, on 15 February $2005(19: 20 \mathrm{~h})$ at $21.1^{\circ} \mathrm{C}$ air temperature. 


\section{Natural History}

Numerous specimens of the new species were heard in the evening in dense primary forest directly next to Camp Simpona campsite, calling from leaves in bushes and on trees at perch heights of 1-2 m above the ground.

\section{Advertisement calls}

Calls of the holotype (ZSM 349/2005) were recorded at Camp Simpona, Marojejy National Park, on 15 February $2005(19: 20 \mathrm{~h})$ at $21.1^{\circ} \mathrm{C}$ air temperature. They have been published by Vences et al. (2006; $\mathrm{CD} 3$, Track 64). The call is a single melodious note that is repeated at regular intervals. Note duration ranges from 384-443 ms $(418 \pm 16 ; \mathrm{n}=11)$, duration of intervals between notes varies between 2504 $3200 \mathrm{~ms}(2797 \pm 243 ; \mathrm{n}=10)$. Note repetition rate is approximately $18-19$ notes/minute. The dominant frequency ranges between $3990-4028 \mathrm{~Hz}(4010 \pm 13 ; \mathrm{n}=11)$.

\section{Molecular differentiation}

DNA sequences of various mitochondrial genes determined from the holotype of Platypelis ravus were included in a comprehensive molecular analysis of cophyline phylogeny, under the name Platypelis sp. 2 (Wollenberg et al. 2008), and are deposited in GenBank under accession numbers EU341101 (12S and 16S genes) and EU341035 (cytochrome $b$ gene). According to this study, the species is deeply genetically divergent from other Platypelis and was grouped by some analyses as sister species of Platypelis milloti. According to Vieites et al. (2009) the pairwise uncorrected sequence divergence (p-distance) in a fragment of the $16 \mathrm{~S}$ rRNA gene of $P$. ravus (as $P$. sp. 4) to all other cophylines was above $6 \%$.

\section{Discussion}

With the description of Platypelis ravus sp. nov. we add a distinctive new species to the genus Platypelis which represents - together with P. tetra (see Andreone et al. 2003) - the smallest species of the Platypelis / Cophyla clade. Phylogenetic analyses (Wollenberg et al. 2008) placed the new species with some confidence sister to $P$. milloti. Although at first glance these two species are very distinctive in numerous characters, including size and advertisement calls, it is interesting that they bear some similarities in the dorsal colour pattern. Platypelis milloti has a dorsal pattern of strongly contrasting black blotches of almost the same shape as the poorly contrasting dark blotches in P. ravus sp. nov. (see pictures in Glaw \& Vences 2007). Also the light bar between the eyes and the vertebral line typical for $P$. ravus sp. nov. are seen more strongly expressed in $P$. milloti. Furthermore, the general ventral pattern is similar, except that the posterior venter is coloured red in $P$. milloti and yellow in $P$. ravus sp. nov. It is therefore appealing to hypothesize that this similarity of colour pattern between the two species is due to common ancestry.

Platypelis ravus sp. nov. is so far only known from its type locality. Own surveys in rainforests of other mountain massifs in northern Madagascar at similar elevations (e.g. Montagne d'Ambre, Manongarivo, Tsaratanana, Makira, at elevations of 900-2500 m) have so far failed to yield additional specimens attributable to $P$. ravus sp. nov., and we therefore cannot exclude that this species is indeed endemic to the Marojejy massif, as it seems to be the case for several other frog species occurring at comparable elevation in this mountain massif(e.g. Gephyromantis tahotra Glaw, Köhler \& Vences, 2011, G. tandroka Glaw \& Vences, 2001, G. schilfi Glaw \& Vences, 2000). In another survey at Marojejy, Raselimanana et al. (2000) identified five species of the Platypelis / Cophyla clade (P. barbouri, P. grandis, P. tsaratananaensis, $P$. tuberifera and $C$. occultans) and we cannot exclude that their high altitude records of $C$. occultans (recorded form 350-1300 m altitude) include $P$. ravus sp. nov., a similarly tiny species. However, as we are aware of only six specimens from a single locality, we suggest to consider $P$. ravus sp. nov. 'Data Deficient' according to the IUCN Red List criteria (IUCN 2001). 


\section{Acknowledgements}

Fieldwork was carried out in the framework of cooperation accords among the Departément de Biologie Animale, Université d'Antananarivo, the Association Nationale pour la Gestion des Aires Protegées, the Zoological Museum, University of Amsterdam, and the Zoologische Staatssammlung München. Permits for collection and export of specimens were kindly issued by the Ministère des Eaux et Forêts of Madagascar. We are grateful to Roger-Daniel Randrianiaina for his help in the field.

\section{References}

AmphibiaWeb 2012. Information on amphibian biology and conservation. [web application]. Berkeley, California: AmphibiaWeb. Available from http://amphibiaweb.org/ [accessed 7 Jan. 2012].

Andreone F., Fenolio D.B. \& Walvoord M.E. 2003. Two unknown arboreal frogs (genus Platypelis) described from the rainforests of northeastern Madagascar (Microhylidae: Cophylinae). Current Herpetology 22 (2): 91-100. http://dx.doi.org/10.5358/hsj.22.91

Andreone F., Vences M., Vieites D.R., Glaw F. \& Meyer A. 2005. Recurrent ecological adaptations revealed through a molecular analysis of the secretive cophyline frogs of Madagascar. Molecular Phylogenetics and Evolution 34 (2): 315-322. http://dx.doi.org/10.1016/j.ympev.2004.10.013

Blommers-Schlösser R.M.A. 1975. Observations on the larval development of some Malagasy frogs, with notes on their ecology and biology (Anura: Dyscophinae, Scaphiophryninae and Cophylinae). Beaufortia 24 (309): 7-26.

Blommers-Schlösser R.M.A. \& Blanc C.P. 1991. Amphibiens (première partie). Faune de Madagascar 75: $1-380$.

Glaw F. \& Vences M. 2007. A Field Guide to the Amphibians and Reptiles of Madagascar. $3^{\text {rd }}$ Ed. Vences \& Glaw Verlag, Köln.

IUCN 2001. IUCN Red List Categories and Criteria. Version 3.1. IUCN, Species Survival Commission, Gland, Switzerland \& Cambridge, U.K.

Kurabayashi A., Matsui M., Belabut D.M., Yong H.S., Ahmad N., Sudin A., Kuramoto M., Hamidy A. \& Sumida M. 2011. From Antarctica or Asia? New colonization scenario for Australian-New Guinean narrow mouth toads suggested from the findings on a mysterious genus Gastrophrynoides. BMC Evolutionary Biology 11: e175. http://dx.doi.org/10.1186/1471-2148-11-175

Raselimanana A.P., Raxworthy C.J. \& Nussbaum R.A. 2000. Herpetofaunal species diversity and elevational distribution within the Parc National de Marojejy, Madagascar. Fieldiana Zoology (N.S.) 97: 157-174.

Van Bocxlaer I., Roelants K., Biju S.D., Nagaraju J. \& Bossuyt F. 2006. Late Cretaceous vicariance in Gondwanan amphibians. PLoS ONE 1 (1): e74. http://dx.doi.org/10.1371/journal.pone.0000074

Van der Meijden A., Vences M., Hoegg S., Boistel R., Channing A. \& Meyer A. 2007. Nuclear gene phylogeny of narrow-mouthed toads (family: Microhylidae) and a discussion of competing hypotheses concerning their biogeographical origins. Molecular Phylogenetics and Evolution 44 (3): 1017-1030. http://dx.doi.org/10.1016/j.ympev.2007.02.008

Vences M., Glaw F., Köhler J. \& Wollenberg K.C. 2010. Molecular phylogeny, morphology and bioacoustics reveal five additional species of arboreal microhylids of the genus Anodonthyla from Madagascar. Contributions to Zoology 79: 1-32.

Vences M., Glaw F. \& Marquez R. (eds) 2006. The Calls of the Frogs of Madagascar. 3 Audio CD's and booklet. Alosa, Barcelona. 
Vieites D.R., Wollenberg K.C., Andreone F., Köhler J., Glaw F. \& Vences M. 2009. Vast underestimation of Madagascar's biodiversity evidenced by an integrative amphibian inventory. Proceedings of the National Academy of Sciences of the U.S.A. 106 (20): 8267-8272. http://dx.doi.org/10.1073/ pnas.0810821106

Wollenberg K.C., Vieites D.R., van der Meijden A., Glaw F., Cannatella D.C. \& Vences M. 2008. Patterns of endemism and species richness in Malagasy cophyline frogs support a key role of mountainous areas for speciation. Evolution 62 (8): 1890-1907. http://dx.doi.org/10.1111/j.1558-5646.2008.00420.x

Manuscript received on: 10 November 2011

Manuscript accepted on: 26 January 2012

Published on: 14 March 2012

Topic editor: Rudy Jocqué

In compliance with Article 8.6 of the ICZN, printed versions of all papers are deposited in the libraries of the institutes that are members of the EJT consortium: Muséum national d'Histoire naturelle, Paris, France; National Botanic Garden of Belgium, Meise, Belgium; Royal Museum for Central Africa, Tervuren, Belgium; Natural History Museum, London, United Kingdom; Royal Belgian Institute of Natural Sciences, Brussels, Belgium; Natural History Museum of Denmark, Copenhagen, Denmark. 